Article

\title{
Insecticidal Effect of Zinc Oxide Nanoparticles against Spodoptera frugiperda under Laboratory Conditions
}

\author{
Sarayut Pittarate ${ }^{1}$, Julius Rajula ${ }^{1}$, Afroja Rahman ${ }^{1}$, Perumal Vivekanandhan ${ }^{2} \mathbb{D}$, Malee Thungrabeab ${ }^{3}$, \\ Supamit Mekchay ${ }^{4,5}$ and Patcharin Krutmuang ${ }^{1,5, * \text { (D) }}$
}

1 Department of Entomology and Plant Pathology, Faculty of Agriculture, Chiang Mai University, Chiang Mai 50200, Thailand; sarayut_pit@cmu.ac.th (S.P.); rajula_j@cmu.ac.th (J.R.); afroja_r@cmu.ac.th (A.R.)

2 Society for Research and Initiatives for Sustainable Technologies and Institutions, Grambharti, Amarapur Rd, Gujarat 382735, India; Mosqvk@gmail.com

3 Agricultural Technology Research Institute, Rajamangala University of Technology Lanna, Lampang 52000, Thailand; mthungrabeab@rmutl.ac.th

4 Department of Animal and Aquatic Sciences, Faculty of Agriculture, Chiang Mai University, Chiang Mai 50200, Thailand; supamit.m@cmu.ac.th

5 Innovative Agriculture Research Center, Faculty of Agriculture, Chiang Mai University, Chiang Mai 50200, Thailand

* Correspondence: patcharin.k@cmu.ac.th; Tel.: +66-865-863-008

check for

updates

Citation: Pittarate, S.; Rajula, J.; Rahman, A.; Vivekanandhan, P.; Thungrabeab, M.; Mekchay, S.; Krutmuang, P. Insecticidal Effect of Zinc Oxide Nanoparticles against Spodoptera frugiperda under Laboratory Conditions. Insects 2021 12, 1017. https://doi.org/10.3390/ insects12111017

Academic Editor: Zhenying Wang

Received: 28 September 2021

Accepted: 8 November 2021

Published: 11 November 2021

Publisher's Note: MDPI stays neutral with regard to jurisdictional claims in published maps and institutional affiliations.

Copyright: (c) 2021 by the authors. Licensee MDPI, Basel, Switzerland. This article is an open access article distributed under the terms and conditions of the Creative Commons Attribution (CC BY) license (https:// creativecommons.org/licenses/by/ $4.0 /)$.
Simple Summary: Fall armyworm has devastated several crops around the world, especially maize that is widely grown and utilized globally. Also, it has been known to cause a lot of damage in rice fields. However, controlling this pest has been a challenge to farmers due to its ability to reproduce faster and its development of resistance to synthetic chemicals, among other factors. Moreover, synthetic chemicals are a threat to the environment and humanity. For these reasons, we are constantly looking for safer yet effective means of controlling this pest, and nanotechnology comes in handy. Zinc Oxide nanoparticles have proved to be efficacious to several insect pests, of which some are in the same genus as Spodoptera frugiperda. This study aimed to find out the insecticidal effects of $\mathrm{ZnO}$ nanoparticles on $\mathrm{S}$. frugiperda under laboratory conditions. We observed body deformations, reduced fecundity, reduced oviposition, and mortality when insects were fed on food treated with several concentrations of $\mathrm{ZnO}$ nanoparticles, yet the ones fed on control were normal in all the aspects. Therefore, we recommend $\mathrm{ZnO}$ nanoparticles for further studies with the aim of using them as an alternative control agent against fall armyworm under field conditions.

Abstract: Fall armyworm Spodoptera frugiperda is a major pest of corn, rice, and sorghum among other crops usually controlled using synthetic or biological insecticides. Currently, the new invention of nanotechnology is taking root in the agricultural industry as an alternative source of pest management that is target-specific, safe, and efficient. This study sought to determine the efficacy of commercial Zinc Oxide $(\mathrm{ZnO})$ nanoparticles (NPs) towards S. frugiperda under laboratory conditions. ZnO NPs were diluted into different concentrations (100-500 ppm), where the baby corn used to feed the S. frugiperda larvae was dipped. The development of the insect feeding on food dipped in $\mathrm{ZnO}$ solution was significantly $(p<0.05)$ affected, and the number of days that the insect took to complete its life cycle had a significant difference compared to the control. There was a significant difference in the adults' emergence in all the concentrations of ZnO NPs compared to the control, with over $90 \%$ of the eggs successfully going through the life cycle until adult emergence. Additionally, several body malformations were observed throughout the lifecycle of the insect. Also, the fecundity of the females was greatly affected. The findings of this study suggest the possibility of exploitation of $\mathrm{ZnO}$ nanoparticles not only to manage $S$. frugiperda but to significantly reduce their population in the ecosystem through body deformations, reduced fecundity, reduced oviposition, and hatchability of eggs. It will be a valuable tool in integrated pest management regimens. 
Keywords: malformations; nanotechnology; Spodoptera frugiperda; zinc oxide nanoparticles

\section{Introduction}

Spodoptera frugiperda (Smith, 1797) otherwise, known as Fall armyworm has been a cause of menace to the maize crop for a long period mostly in the tropics and subtropics of America. That notwithstanding, the insect invades a number of other crops in the gramineous family including sorghum, millet, rice, Bermuda grass among others, making it a serious pest in the agricultural industry [1]. Recently, the insect has been reported in various African and Asian countries including Thailand. It has been estimated that fall armyworm has instigated a loss of between 2 and 6 billion U.S. dollars in Europe and Africa combined annually [2]. In America, the losses caused are so enormous, and controlling the insect has been a daunting task. For a long time, chemical pesticides have been employed in the control of this pest in America, Europe, and now the newly invaded regions in Africa and Asia. However, the increased use of chemical insecticides causes environmental contamination, bioaccumulation, and human toxicity. Also, prolonged application of the compounds found in these chemicals accounts for resistance in several insect pests in agriculture including fall armyworm [3]. That notwithstanding, for chemical pesticides to work effectively, timing must be accurate for proper management of the same.

Globally, scientists and governments are shifting from chemical-based agriculture to green agriculture in order to ensure safety of the environment, animals, and human beings. This they tend to achieve by using plant extracts, entomopathogenic microorganisms, and nanoparticles to control plant pests and diseases [4]. Also, plants have also risen to the task of defending themselves from herbivory attack by producing volatile organic compounds (VOCs) that have been observed to reduce the insect invasion by up to $90 \%$. This has been observed in maize to control Ostrinia nubilalis; the stored products pest Sitophilus granaries and many other insects, especially the ones that cause injury to their host as the VOCs are triggered by injury. Luckily, this is not dependent on their taxonomic affinities. More is being explored by scientists in this area so that the volatiles can be commercially availed for management of plant insect pests [5-7]. Additionally, a variety of metal particles such as zinc $(\mathrm{Zn})$, silver $(\mathrm{Ag})$, copper $(\mathrm{Cu})$, silica $(\mathrm{Si})$, gold $(\mathrm{Au})$, aluminum $(\mathrm{Al})$, and metallic oxides such as Titanium and Zinc oxides are being synthesized for use in controlling plant pests and diseases [8].

Nanoparticles are characterized by atomic or molecular size less than $100 \mathrm{~nm}$ [9]. Slowly but steadily, they have gained popularity due to their fascinating properties compared to their competitors in terms of applications [10]. Their high solubility in water and stability of the formulations are outstanding as compared to other pesticides [11,12]. Additionally, nanoparticles have proved to be efficacious against plant pathogens, weeds, and insect pests. Also, they have been added to the formulations of insecticides and insect repellents. Fortunately, the nanoparticles do not pose health hazards to the environment and public health compared to the traditional chemical pesticides [13-15]. However, the detailed mechanisms of nano-particles have not been understood to a convincing conclusion and therefore, need in-depth examination or experimentations of their interaction with the biological systems before designing consumable products [9]. Generally, nanoparticles are known to permeate through plant cells hence they become nanocarriers making them efficient in targeting the pest [12]. Zinc oxide nanoparticles (ZnO NPs) are among the significant metal oxides popular due to their chemical and physical peculiarity $[16,17]$. Notably, $\mathrm{ZnO}$ has proved to possess great potential in the biosynthesis of nanoparticles for clinical purposes compared to other oxides. Moreover, several studies have confirmed that $\mathrm{ZnO}$ nanoparticles can be synthesized using various plant extracts such as Hibiscus rosasinensi and Cassia auriculata [18]. That notwithstanding, $\mathrm{ZnO}$ nanoparticles synthesized using plant extracts as reducing agents have proved to have sturdy antimicrobial efficacy against Aspergillus spp., Pseudomonas aeruginosa, Staphylococcus aureus, and Klebsiella pneu- 
monia $[19,20]$. This study, therefore, sought to determine the efficacy of commercial $\mathrm{ZnO}$ nanoparticles towards Spodoptera frugiperda under laboratory conditions. Additionally, the study elucidated the developmental interference after the consumption of food dipped into $\mathrm{ZnO}$ nanoparticles solutions of different concentrations.

\section{Materials and Methods}

\subsection{Area of the Study}

The experiments were conducted at the Laboratory of Insect Pathology, Department of Entomology and Plant Pathology, Faculty of Agriculture, Chiang Mai University, Muang District, Chiang Mai province, Thailand. The region is a plain with an altitude of $311 \mathrm{~m}$ above sea level at a longitude of $98.97^{\circ} \mathrm{E}$ and a latitude of $18.77^{\circ} \mathrm{N}$. Due to the invasive nature of the fall armyworm, all observations were recorded under quarantine facilities.

\subsection{Fall Armyworm Rearing}

Larvae, pupae, and adults of fall armyworm (FAW) used in this study are the laboratory strain maintained at the Insect Pathology Laboratory, Department of Entomology and Plant Pathology, Faculty of Agriculture, Chiang Mai University, Thailand. This colony originated from a wild strain larvae captured from the cornfield at Mae-Hia Agricultural Training and Research Center, Faculty of Agriculture, Chiang Mai University during the corn/maize growing season and had been maintained in plastic containers $(19 \mathrm{~cm}$ in width by $27 \mathrm{~cm}$ in length by $8 \mathrm{~cm}$ in height) and fed on baby corn under laboratory room conditions at $26 \pm 1{ }^{\circ} \mathrm{C}$ with a photoperiod of $12: 12 \mathrm{~h}$ (dark:light) and $70 \pm 10 \%$ humidity.

\subsection{Source of Zinc Oxide Nanoparticles}

Extra pure zinc oxide $(25-50 \mathrm{~nm})$ nanoparticles were purchased from Green Nanotechnology (Chiangmai, Thailand). Complete characterization of the particles is available at the company and can be accessed through their website http://www.nano.kmitl.ac.th (accessed on 4 November 2021). Naturally, the aqueous suspensions of nanoparticles are stable but usually, they suffer aggregation in water; hence, the suspensions were vortexed for 10-20 min before use in the treatments [3].

\subsection{Bioassay of Fall Armyworm Reared on Different Concentration ZnO NPs}

Due to the invasive status of this insect pest in Thailand, the egg batches used in this study were derived from the first generation of Insect Pathology Laboratory (IPL) stocks of FAW females captured from the cornfield at Mae-Hia Agricultural Training and Research Center, Faculty of Agriculture, Chiang Mai University as previously mentioned.

The egg batches that were oviposited were maintained under controlled conditions, and upon hatching, the neonate larvae were individually placed in plastic containers measuring (sauce cup $6 \mathrm{~cm} \times 3 \mathrm{~cm} ; 3 \mathrm{oz}$ ). Various concentrations were prepared by diluting the original $\mathrm{ZnO}$ nanoparticles using distilled water to achieve 100, 200, 300, 400, and $500 \mathrm{ppm}$ respectively. Thereafter, the achieved concentrations were administered orally to the neonate larvae of fall armyworm by feeding them on baby corn weighing approximately 1-3 g dipped in the various $\mathrm{ZnO}$ NPs concentrations. This was done every 3 days until they reached the pre-pupal stage. On the other hand, the control group were fed on baby corn that were not charged with nanoparticles [9]. Each day, the development and survival of larvae were observed for each treatment. Larval stages were L1, L2, L3, L4, L5, and L6. Pupal weight, width, length, and deformed were recorded from the surviving insects, and sex determination was conducted at the pupal stage by observing under Zeiss Stemi 508 Compound microscope [21]. Observations of insect biological parameters and development including duration of instars, fertility, deformities, and longevity of individuals were recorded daily. The duration of instars was determined by the number of days the larvae takes from one instar to the next from neonate larvae to the sixth instar. Fertility was determined by the number of eggs oviposited by the females and their hatchability and deformities was determined by observing the physical appearance of the 
larvae, pupa, and adults. Each treatment had four replications of twenty larvae each and the completely randomized block design was used.

\subsection{Oviposition Preference}

To determine which cumulative $\mathrm{ZnO} \mathrm{NPs}^{\prime}$ different concentrations in adults are preferred for oviposition. Oviposition substrate was used to build the resulting eggs corresponding to the treatment food they were offered. After adult emergence, a total of 30 FAW pairs were used for this experiment, with one virgin pair (one male and one female) released at the center of a plastic container covered with plastic caps (drinking cups; $11.5 \mathrm{~cm}$ in width $\times 14.5 \mathrm{~cm}$ in length; $300 \mathrm{oz}$.), for a total of five replications. Female adults were allowed to oviposit for 7 days and fed with a $10 \%$ honey solution provided in small plastic boxes. The source of food used to nourish adults was being replaced at 2-3-day intervals. Folded pieces of paper (4 $\mathrm{cm}$ in width by $10 \mathrm{~cm}$ length) were hung in the rearing cage for egg-laying. Egg masses, egg numbers, and percent egg hatching were recorded daily until the death of each individual [22].

\subsection{Statistical Analysis}

Standard procedures were followed to record the data. The data collected was analyzed statistically using a one-way analysis of variance (ANOVA) with Ducan's posthoc test to assess the oviposition preference and pupal weight, length, and width of FAW among different concentrations of ZnO NPs. The treatment means were compared using Tukey's for their significance at the $0.05 \%$ probability level. The FAW egg masses and number of eggs recorded in the different concentrations of $\mathrm{ZnO}$ NPs were compared by paired T-test. Differences were considered significant at $p<0.05$. The statistical analyses were conducted using the IBM SPSS Statistical Software package version 23.0 ( IBM Corp, Armonk, NY, USA, 2015).

\section{Results}

\subsection{The Development of FAW Fed on Baby Corn Dipped in Different Concentrations of $\mathrm{ZnO}$ Nanoparticles}

When the insect was fed on food dipped in $\mathrm{ZnO}$ nanoparticles, the mortality rate observed was not significant; however, there was a significant difference in the development of the insect from larval state to adults. The results obtained demonstrate the insecticidal activity of $\mathrm{ZnO}$ nanoparticles when orally ingested by the insect under a controlled environment in the assumption that no factors interfere with the outcome. The larvae feeding on food dipped in ZnO NPs solution were affected and the number of days taken to complete the lifecycle had a significant difference compared to the control. Also, a significant difference was observed in the emergence of adults compared to the control that had over $90 \%$ of the eggs successfully going through the cycle till adult emergence (Tables 1-3). When the pupal weights were taken, we observed significant differences $(p<0.05)$. The pupa fed on ZnO NPs treated baby corn weighed much less than the pupa from the control. 
Table 1. Development time and adult longevity (Mean \pm SE) of FAW fed on dip food (baby-corn) in ZnO NPs difference concentrations (100-500 ppm).

\begin{tabular}{|c|c|c|c|c|c|c|c|c|c|c|c|c|c|c|}
\hline \multirow{2}{*}{ Parameters } & \multicolumn{2}{|r|}{100} & \multicolumn{2}{|r|}{200} & \multicolumn{2}{|r|}{300} & \multicolumn{2}{|r|}{400} & \multicolumn{2}{|r|}{500} & \multicolumn{2}{|r|}{ Control } & \multirow{2}{*}{ df } & \multirow{2}{*}{$\mathbf{F}$} \\
\hline & $\mathrm{n}$ & Days & $\mathrm{n}$ & Days & $\mathrm{n}$ & Days & $\mathrm{n}$ & Days & $\mathrm{n}$ & Days & $\mathrm{n}$ & Days & & \\
\hline Egg & 80 & $2.50 \pm 0.000$ & 80 & $2.50 \pm 0.000$ & 80 & $2.50 \pm 0.00$ & 80 & $2.50 \pm 0.000$ & 80 & $2.50 \pm 0.000$ & 80 & $2.50 \pm 0.000$ & - & - \\
\hline L1 & 80 & $2.30 \pm 0.105 \mathrm{a}$ & 80 & $2.50 \pm 0.115 \mathrm{ab}$ & 79 & $2.60 \pm 0.112 \mathrm{ab}$ & 80 & $2.65 \pm 0.109 \mathrm{ab}$ & 80 & $2.85 \pm 0.082 b$ & 80 & $2.45 \pm 0.114 \mathrm{ab}$ & 5 & 3.100 \\
\hline L2 & 80 & $2.15 \pm 0.167 \mathrm{a}$ & 80 & $2.25 \pm 0.160 \mathrm{a}$ & 79 & $2.30 \pm 0.147 \mathrm{a}$ & 80 & $2.35 \pm 0.109 \mathrm{a}$ & 80 & $2.55 \pm 0.114 \mathrm{a}$ & 80 & $2.00 \pm 0.126 \mathrm{a}$ & 5 & 1.796 \\
\hline L3 & 80 & $1.60 \pm 0.112 \mathrm{a}$ & 80 & $1.60 \pm 0.112 \mathrm{a}$ & 76 & $1.95 \pm 0.114 \mathrm{ab}$ & 80 & $2.35 \pm 0.131 b c$ & 80 & $2.40 \pm 0.134 c$ & 80 & $1.85 \pm 0.109 \mathrm{a}$ & 5 & 8.671 \\
\hline L4 & 73 & $1.50 \pm 0.115 \mathrm{a}$ & 77 & $1.55 \pm 0.135 \mathrm{a}$ & 73 & $1.55 \pm 0.114 \mathrm{a}$ & 76 & $1.75 \pm 0.123 \mathrm{ab}$ & 80 & $1.85 \pm 0.820 \mathrm{ab}$ & 80 & $2.05 \pm 0.135 b$ & 5 & 3.292 \\
\hline L6 & 39 & $2.00 \pm 0.126 \mathrm{a}$ & 34 & $1.90 \pm 0.176 \mathrm{a}$ & 34 & $2.50 \pm 0.154 \mathrm{ab}$ & 37 & $2.80 \pm 0.172 b c$ & 40 & $3.30 \pm 0.164 c$ & 76 & $2.20 \pm 0.156 \mathrm{a}$ & 5 & 11.241 \\
\hline Prepupa & 39 & $1.50 \pm 0.115 \mathrm{a}$ & 34 & $1.55 \pm 0.114 \mathrm{a}$ & 34 & $1.60 \pm 0.134 \mathrm{a}$ & 37 & $1.65 \pm 0.131 \mathrm{a}$ & 40 & $2.10 \pm 0.143 b$ & 76 & $1.45 \pm 0.114 \mathrm{a}$ & 5 & 3.505 \\
\hline Pupa & 39 & $9.15 \pm 0.167 b c$ & 32 & $8.45 \pm 0.246 b$ & 34 & $8.95 \pm 170 \mathrm{bc}$ & 36 & $9.70 \pm 0.219 c$ & 40 & $7.30 \pm 0.317 \mathrm{a}$ & 76 & $9.55 \pm 0.114 c$ & 5 & 16.701 \\
\hline Adults & 30 & - & 20 & - & 24 & - & 23 & - & 26 & - & 72 & - & - & - \\
\hline Female & 22 & $8.7 \pm 0.524 \mathrm{~b}$ & 11 & $8.45 \pm 0.515 b$ & 16 & $7.85 \pm 0.554 b$ & 14 & $5.2 \pm 0.374 \mathrm{a}$ & 17 & $5.05 \pm 0.394 \mathrm{a}$ & 39 & $13.15 \pm 0.284 \mathrm{c}$ & 5 & 42.962 \\
\hline Male & 8 & $07.05 \pm 0.526 b$ & 9 & $04.95 \pm 0.276 \mathrm{a}$ & 8 & $4.65 \pm 2.84 \mathrm{a}$ & 9 & $4.65 \pm 2.84 \mathrm{a}$ & 9 & $4.80 \pm 0.445 \mathrm{a}$ & 33 & $09.55 \pm 0.312 \mathrm{c}$ & 5 & 29.502 \\
\hline
\end{tabular}


Table 2. Pupal weight, width, and Length (Mean \pm SE) of FAW fed on dip food (baby-corn) in ZnO NPs different concentrations (100-500 ppm) and control.

\begin{tabular}{cccc}
\hline \multirow{2}{*}{$\begin{array}{c}\text { Treatments } \\
\text { (ZnONPs: } \mathbf{p p m})\end{array}$} & Weight & Width & Length \\
\cline { 2 - 4 } & $0.160 \pm 0.007 \mathrm{~b}$ & $0.426 \pm 0.008 \mathrm{a}$ & $1.397 \pm 0.031 \mathrm{a}$ \\
\hline 100 & $0.130 \pm 0.005 \mathrm{a}$ & $0.432 \pm 0.006 \mathrm{a}$ & $1.416 \pm 0.025 \mathrm{a}$ \\
\hline 200 & $0.125 \pm 0.005 \mathrm{a}$ & $0.422 \pm 0.010 \mathrm{a}$ & $1.376 \pm 0.024 \mathrm{a}$ \\
\hline 300 & $0.120 \pm 0.006 \mathrm{a}$ & $0.415 \pm 0.007 \mathrm{a}$ & $0.415 \pm 0.007 \mathrm{a}$ \\
\hline 400 & $0.113 \pm 0.006 \mathrm{a}$ & $0.407 \pm 0.007 \mathrm{a}$ & $1.407 \pm 0.029 \mathrm{a}$ \\
\hline 500 & $0.186 \pm 0.002 \mathrm{c}$ & $0.438 \pm 0.007 \mathrm{a}$ & $1.504 \pm 0.015 \mathrm{~b}$ \\
\hline Control & 5 & 5 & 5 \\
\hline $\mathrm{df}$ & 27.288 & 2.112 & 3.457 \\
\hline $\mathrm{F}$ & & &
\end{tabular}

Table 3. Mean $( \pm \mathrm{SE})$ percentages of pupa and adult normal/abnormal/dead of FAW fed on food (baby-corn) dipped in ZnO NPs different concentrations (100-500 ppm).

\begin{tabular}{|c|c|c|c|c|c|c|c|c|}
\hline \multirow{2}{*}{ Parameters } & \multicolumn{6}{|c|}{ Treatments (ZnONPs: ppm) } & \multirow{2}{*}{ df } & \multirow{2}{*}{$\mathbf{F}$} \\
\hline & 100 & 200 & 300 & 400 & 500 & Control & & \\
\hline \multicolumn{9}{|l|}{ Pupa } \\
\hline$\%$ Normal & $48.75 \pm 5.907 a$ & $40.00 \pm 4.564 \mathrm{a}$ & $42.50 \pm 3.227 \mathrm{a}$ & $45.00 \pm 3.536 \mathrm{a}$ & $50.00 \pm 2.041 \mathrm{a}$ & $95.00 \pm 2.887 \mathrm{~b}$ & 5 & 28.077 \\
\hline$\%$ Abnormal & $3.75 \pm 1.250 \mathrm{a}$ & $5.00 \pm 2.041 \mathrm{a}$ & $7.50 \pm 1.443 \mathrm{a}$ & $7.50 \pm 1.443 \mathrm{a}$ & $6.25 \pm 1.250 \mathrm{a}$ & $2.50 \pm 1.443 \mathrm{a}$ & 5 & 1.846 \\
\hline$\%$ Dead & $7.50 \pm 1.443 \mathrm{ab}$ & $10.00 \pm 2.041 b$ & $5.00 \pm 0.000 \mathrm{ab}$ & $8.75 \pm 1.250 \mathrm{ab}$ & $11.25 \pm 2.394 b$ & $2.50 \pm 1.443 \mathrm{a}$ & 5 & 4.080 \\
\hline \multicolumn{9}{|l|}{ Adults } \\
\hline$\%$ Normal & $16.25 \pm 2.394 \mathrm{ab}$ & $15.00 \pm 2.041 \mathrm{ab}$ & $17.50 \pm 1.443 \mathrm{ab}$ & $12.50 \pm 1.443 \mathrm{a}$ & $21.25 \pm 1.250 \mathrm{~b}$ & $87.50 \pm 1.443 \mathrm{c}$ & 5 & 287.506 \\
\hline$\%$ Abnormal & $21.25 \pm 5.154 \mathrm{~b}$ & $10.00 \pm 2.041 \mathrm{ab}$ & $12.50 \pm 2.500 \mathrm{ab}$ & $16.25 \pm 3.750 \mathrm{ab}$ & $11.25 \pm 3.146 \mathrm{ab}$ & $2.50 \pm 1.443 \mathrm{a}$ & 5 & 3.774 \\
\hline
\end{tabular}

Different letters indicate significant differences.

\section{2. $\mathrm{ZnO}$ NPs Induced Morphological Changes in the Insect}

Exposure to ZnO NPs caused body deformities in all stages of the life cycle from larvae to adults. Figures 1-4 clearly show the body malformations instigated after the ingestion of baby corn dipped in ZnO NPs. Each figure clearly shows the typical morphology of larvae fed on control and the malformations that are caused due to the ingestion of food dipped in ZnO NPs. Compared to the control, there were significant differences $(p<0.05)$ in oviposition, larval development, pupal development, and adult emergence. The pupal weight, length, and width were taken, and it was observed that there was a significant difference in the weight of all the other treatments compared to the control. Also, the pupal length had a significant difference when the control was compared to the different concentrations of $\mathrm{ZnO}$ NPs. However, the pupal width had no significant difference.
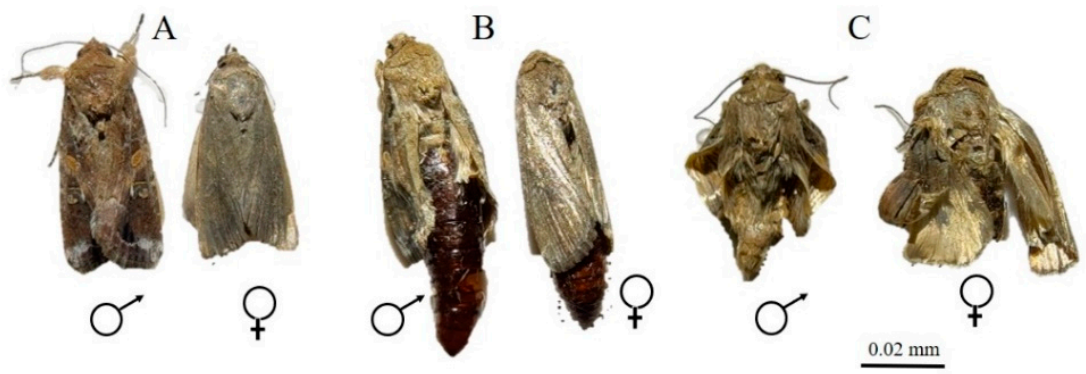

Figure 1. (A) Control male and female after emergence; $(B, C)$ Malformed male and female after emergence. 

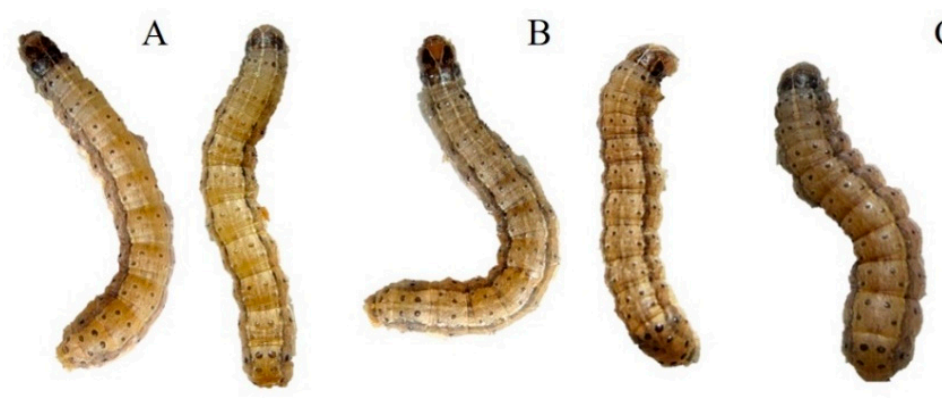

$\mathrm{C}$

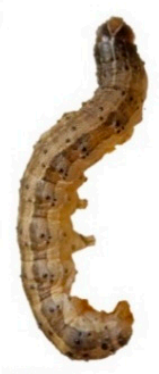

$\underline{0.02 \mathrm{~mm}}$

Figure 2. (A) Control 5th instar larvae; (B,C) Malformed 5th instar larvae.

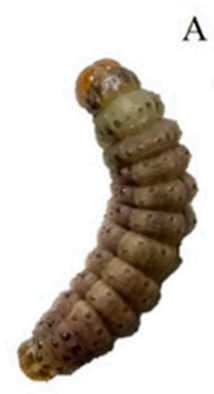

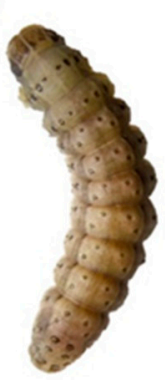

B

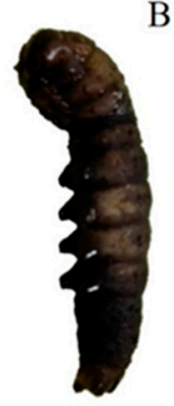

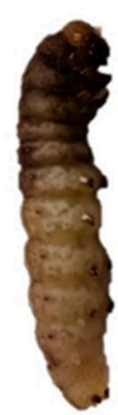

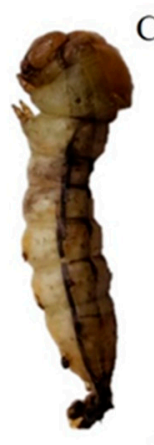

$\mathrm{C}$

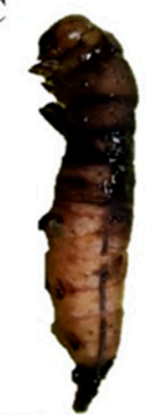

$0.02 \mathrm{~mm}$

Figure 3. (A) Control 6th instar larvae; (B,C) Malformed larvae 6th instar larvae.
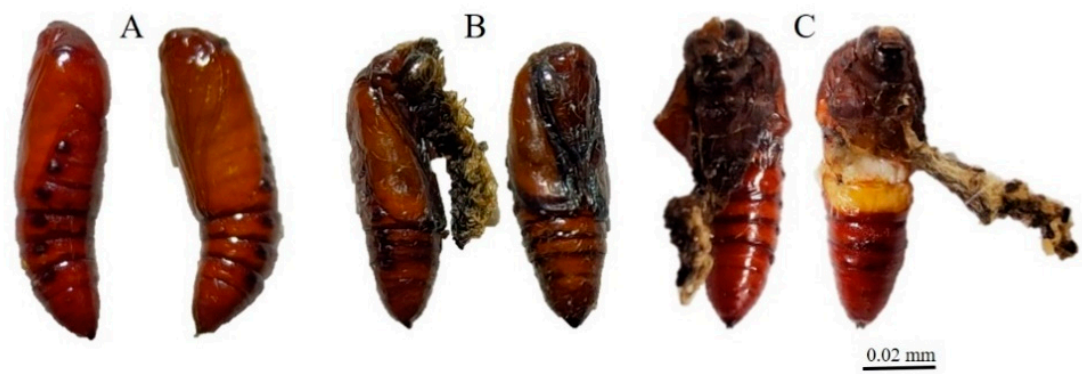

Figure 4. (A) Control pupa; (B,C) Malformed pupa.

\subsection{Mortality of Spodoptera frugiperda Fed on Baby Corn Dipped in ZnO NPs}

Our unpublished data showed mortality of about $40 \%$ of larvae after 10 days of feeding on baby corn dipped in ZnO NPs solution.

\subsection{Effect of ZnO NPs on Fecundity and Fertility of Spodoptera frugiperda}

The effect of ZnO NPs on female fecundity and fertility is presented in Table 4 and Figure 5. There were significant differences $(p<0.05)$ in the number of females that were able to oviposit and the ones that did not oviposit due to $\mathrm{ZnO}$ NPs treatment. For example, in Table 4, out of 22 females who fed on food dipped in $\mathrm{ZnO} \mathrm{NPs,} \mathrm{only} 7$ (31.8\%) proved to be reproductive, while over $74 \%$ of the females who fed on control were oviposited. That notwithstanding, the number of eggs oviposited by the latter was much more than those oviposited by the former. Moreover, the hatchability of the eggs laid by the females who ingested ZnO NPs ranged between 1.92 to $7.64 \%$, while the eggs oviposited by the control hatched $96.4 \%$. Additionally in Figure 5, it was observed that the eggs that were oviposited by females fed on baby corn dipped in ZnO NPs solution were not only a few by only a paltry hatched. 
Table 4. Adult preoviposition period (APOP), total preoviposition period (TPOP), oviposition period, fecundity, and percent hatching parameters.

\begin{tabular}{cccccc}
\hline $\begin{array}{c}\text { Treatments: } \\
\text { (ZnONPs: } \mathbf{p p m})\end{array}$ & Total Females & $\begin{array}{c}\text { Reproductive } \\
\text { Females }\end{array}$ & APOP (Days) & TPOP (Days) & $\begin{array}{c}\text { Oviposition } \\
\text { Period (Days) }\end{array}$ \\
\hline 100 & 22 & 7 & $2.40 \pm 0.152 \mathrm{a}$ & $33.55 \pm 0.738 \mathrm{a}$ & $3.55 \pm 0.303 \mathrm{a}$ \\
\hline 200 & 11 & 8 & $2.85 \pm 0.167 \mathrm{a}$ & $33.45 \pm 0.709 \mathrm{a}$ & $3.50 \pm 0.366 \mathrm{a}$ \\
\hline 300 & 16 & 9 & $2.85 \pm 0.167 \mathrm{a}$ & $34.55 \pm 0.766 \mathrm{a}$ & $2.65 \pm 0.365 \mathrm{a}$ \\
\hline 400 & 14 & 9 & $2.95 \pm 0.185 \mathrm{a}$ & $34.00 \pm 0.533 \mathrm{a}$ & $2.85 \pm 0.365 \mathrm{a}$ \\
\hline 500 & 17 & 8 & $3.05 \pm 0.185 \mathrm{a}$ & $33.20 \pm 0.663 \mathrm{a}$ & $2.55 \pm 0.444 \mathrm{a}$ \\
\hline Control & 39 & 29 & $2.60 \pm 0.152 \mathrm{a}$ & $39.35 \pm 0.519 \mathrm{~b}$ & $5.30 \pm 0.145 \mathrm{~b}$ \\
\hline $\mathrm{df}$ & - & - & 5 & 5 & 5 \\
\hline F & - & - & 2.035 & 12.452 & 8.826 \\
\hline
\end{tabular}

Different letters indicate significant differences.
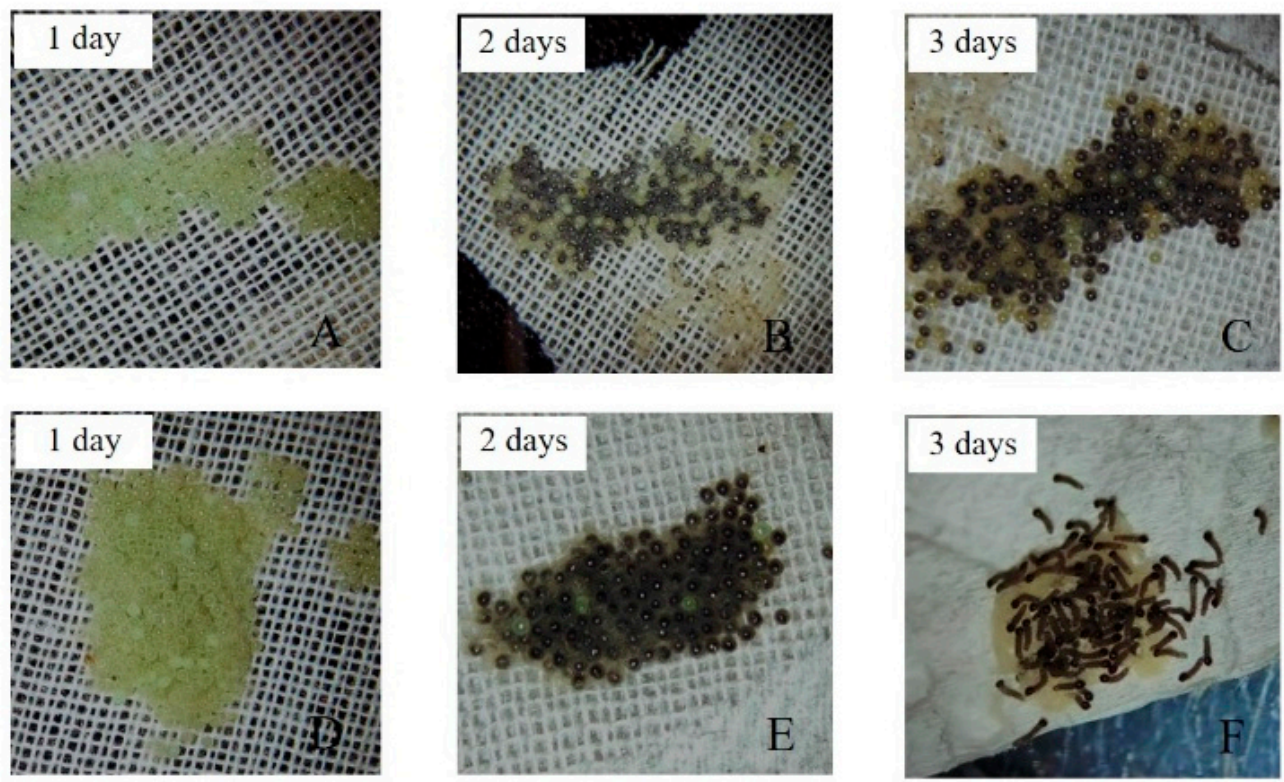

Figure 5. (A-C) = Eggs from adults fed on food dipped in ZnO NPs; (D-F) = Eggs from the adult fed on food dipped in control.

Moreover, the hatchability of the eggs laid by the females that ingested $\mathrm{ZnO}$ NPs ranged between 1.92 to $7.64 \%$ while the eggs oviposited by the control hatched $96.4 \%$.

\subsection{Effects of ZnO NPs on the Longevity of Spodoptera frugiperda}

When treated with different concentrations of $\mathrm{ZnO} N P s$, there was a significant difference $(p<0.05)$ in larval, pupal, male, and female adult longevity. The females who fed on control lasted 13 days, while the males lasted over nine and half days, which was way longer than the rest who ingested $\mathrm{ZnO}$ NPs (Table 1).

\section{Discussion}

This study aimed to determine the insecticidal effect of $\mathrm{ZnO}$ on the development of fall armyworm from neonate larvae to adults. S. frugiperda has majorly been managed using synthetic pesticides and a few biopesticides for the longest time that it has been ravaging crops. However, the use of these synthetic pesticides has damaged the environment and caused resistance to insecticides $[23,24]$. It poses a significant challenge in controlling this insect and hence the need to come up with a more subtle but effective means of controlling 
S. frugiperda that will not be dangerous to the environment and at the same time does not cause resistance to the insect [25]. In this regard, research is being conducted on alternatives that can effectively manage this insect and are also safe for the environment. ZnO NPs have proved to be a promising source of safe insecticides yet effective in controlling S. frugiperda. Also, it has been observed that it can manage several other insect pests at environmentally friendly and low dosages of about $700 \mathrm{mg} \mathrm{mL}^{-1}$ had the highest insect mortality effect [24]. Moreover, ZnO NPs were combined with Thiamethoxam and enhanced its efficacy in the management of Spodoptera litura [22]. The development of S. frugiperda was significantly jeopardized due to their exposure to ZnO NPs as displayed in Table 1. These observations corroborate other findings before with different insects such as rice weevil Sitophilus oryzae and Trialeurodes vaporariorum where mortality was recorded due to exposure to ZnO NPs [26,27]. Also, when leaves infested by Aphis nerii were dipped into various concentrations of ZnO NPs, there was a significant effect on their development [24]. Studies have been carried out on the insecticidal effects of silver nanoparticles and have shown that they can manage the insects that damage crops such as Spodoptera littoralis [28]. Another study using biosynthesized AgNPs showed larvicidal toxicity against Anopheles stephensi, Aedes aegypti, and Culex quinquefasciatus [29]. In addition, green copper nanoparticles when tested against Aedes aegypti, Culex quinquefasciatus, and Anopheles stephensi showed impressive results when measured using $\mathrm{LC}_{50}$ and $\mathrm{LC}_{90}$ [30].

It has been established that when there are body malformations in the insect population, the population is greatly reduced beneath economic levels and that is exactly what we observed in this experiment. There were several body deformations observed throughout the lifecycle of the insect as depicted in Figures 1-4. Causing deformity in the insect pest population in the integrated pest management program is one of the important aspects in controlling pest population below the economic damage level. Apart from ZnO NPs, silica nanoparticles have been observed to reduce pests when sprayed in infested plants [15].

Longevity has been considered as one of the vital characteristics of an insect's life cycle due to the role it plays in maintaining population size. Observably, our results show that when the insects fed on food dipped in different concentrations of ZnO NPs, the longevity of adults had a significant difference when compared to insects fed on food dipped in control Table 1. Previous studies recorded that when the insect pests are exposed to insecticides, their longevity is distorted hence the population plummets [22].

Oviposition was greatly reduced due to ingestion of ZnO NPs as compared to the specimen fed on control-treated baby corn. That notwithstanding, the number of eggs laid by the females that fed on baby corn dipped in $\mathrm{ZnO}$ were fewer than those who fed on food dipped in control. Moreover, the hatchability of eggs was significantly reduced in all the treatment groups compared to the control [31]. A previous study that exposed Drosophila spp. to silver nanoparticles showed that they reduced fertility and vertical climbing in females [32]. Considerably, as a substitute for killing adult insects, it would be beneficial to regulate or manage the insect pest population by plummeting the egg-laying capacity of females and the hatching of the same.

\section{Conclusions}

$\mathrm{ZnO}$ NPs demonstrate a promising potential to be used as an alternative to the more lethal insecticides in controlling $S$. frugiperda and other species. Although the environmental effects of using $\mathrm{ZnO}$ nanoparticles as an insecticide should be studied further, one obvious benefit of using them as insecticides is the low risk of developing resistance by the insects when used for a long time.

The findings of this study suggest the possibility of exploitation of $\mathrm{ZnO}$ nanoparticles not only to control $S$. frugiperda but to significantly reduce their population in the ecosystem through instigation of body deformities, reduced fecundity, reduced oviposition, and reduced hatchability of eggs. It is a valuable tool in integrated pest management regimens. 
Author Contributions: Conceptualization, S.P., P.K. and A.R.; methodology, S.P., P.K. and M.T; software, S.P.; validation, S.P., P.V., A.R. and S.M.; formal analysis, S.P., J.R. and S.M.; investigation, S.P., P.K. and M.T.; resources, P.K., M.T. and S.M.; data curation, S.P., J.R., P.K. and P.V; writingoriginal draft preparation, S.P., J.R.; writing—review and editing, J.R., S.P., P.K. and P.V.; visualization, S.P., A.R. and P.K.; supervision, M.T., P.K., S.M. and P.V.; project administration, M.T., P.K. and S.M.; funding acquisition, P.K. and M.T. All authors have read and agreed to the published version of the manuscript.

Funding: This research received no external funding.

Institutional Review Board Statement: Not applicable.

Data Availability Statement: Not applicable.

Acknowledgments: We would like to acknowledge the Teaching Assistant and Research Assistant (TA/RA) and Presidential Scholarships from the Graduate School, Chiang Mai University. This research work was partially supported by Chiang Mai University.

Conflicts of Interest: The authors declare no conflict of interest. The funders had no role in the design of the study; in the collection, analyses, or interpretation of data; in the writing of the manuscript, or in the decision to publish the results.

\section{References}

1. Bhusal, S.; Chapagain, E. Threats of fall armyworm (Spodoptera frugiperda) incidence in Nepal and it's integrated managementA review. J. Agric. Nat. Resour. 2020, 3, 345-359. [CrossRef]

2. Sartiami, D.; Harahap, I.S.; Kusumah, Y.M.; Anwar, R. First record of fall armyworm (Spodoptera frugiperda) in Indonesia and its occurence in three provinces. IOP Conf. Ser. Earth Environ. Sci. 2020, 468, 012021. [CrossRef]

3. Deka, B.; Babu, A.; Baruah, C.; Barthakur, M. Nanopesticides: A Systematic Review of Their Prospects With Special Reference to Tea Pest Management. Front. Nutr. 2021, 8, 686131. [CrossRef]

4. Abel, C.A.; Scott, M.P. Evaluation of 21 Thailand Maize Germplasms for Resistance to Leaf Feeding Spodoptera frugiperda (Lepidoptera: Noctuidae). J. Kans. Entomol. Soc. 2020, 93, 97-102. [CrossRef]

5. Piesik, D.; Rochat, D.; Delaney, K.J.; Marion-Poll, F. Orientation of European corn borer first instar larvae to synthetic green leaf volatiles. J. Appl. Entomol. 2013, 137, 234-240. [CrossRef]

6. Piesik, D.; Wenda-Piesik, A. Sitophilus granarius responses to blends of five groups of cereal kernels and one group of plant volatiles. J. Stored Prod. Res. 2015, 62, 36-39. [CrossRef]

7. Skoczek, A.; Piesik, D.; Wenda-Piesik, A.; Buszewski, B.; Bocianowski, J.; Wawrzyniak, M. Volatile organic compounds released by maize following herbivory or insect extract application and communication between plants. J. Appl. Entomol. 2017, 141, 630-643. [CrossRef]

8. Kitherian, S. Nano and Bio-nanoparticles for Insect Control. Res. J. Nanosci. Nanotechnol. 2016, 7, 1-9. [CrossRef]

9. Mir, A.H.; Qamar, A.; Qadir, I.; Naqvi, A.H.; Begum, R. Accumulation and trafficking of zinc oxide nanoparticles in an invertebrate model, Bombyx mori, with insights on their effects on immuno-competent cells. Sci. Rep. 2020, 10, 1617. [CrossRef]

10. Sabir, S.; Arshad, M.; Chaudhari, S.K. Zinc oxide nanoparticles for revolutionizing agriculture: Synthesis and applications. Sci. World J. 2014, 2014, 925494. [CrossRef]

11. FAO. Fall Armyworm (Faw). 2017. Available online: https://www.fao.org/3/i7471e/i7471e.pdf (accessed on 25 October 2021).

12. Athanassiou, C.G.; Kavallieratos, N.G.; Benelli, G.; Losic, D.; Usha Rani, P.; Desneux, N. Nanoparticles for pest control: Current status and future perspectives. J. Pest Sci. 2018, 91, 1-15. [CrossRef]

13. Bhattacharyya, T.; Bhaumik, A.; Rani, P.; Mandal, S.; Epidi, T. Nano-particles-A recent approach to insect pest control. Afric. J. Biotechnol. 1995, 9, 3489-3493.

14. Barik, T.K.; Sahu, B.; Swain, V. Nanosilica-From medicine to pest control. Parasitol. Res. 2008, 103, 253-258. [CrossRef]

15. Thabet, A.F.; Boraei, H.A.; Galal, O.A.; El-Samahy, M.F.M.; Mousa, K.M.; Zhang, Y.A.; Tuda, M.; Helmy, E.A.; Wen, J.; Nozaki, T. Silica nanoparticles as pesticide against insects of different feeding types and their non-target attraction of predators. Sci. Rep. 2021, 11, 14484. [CrossRef]

16. Jiang, J.; Pi, J.; Cai, J. The Advancing of Zinc Oxide Nanoparticles for Biomedical Applications. Bioinorg. Chem. Appl. 2018, 2018, 1062562. [CrossRef] [PubMed]

17. Czyżowska, A.; Barbasz, A. A review: Zinc oxide nanoparticles-friends or enemies? Int. J. Environ. Health Res. 2020, 1-17. [CrossRef] [PubMed]

18. Naseer, M.; Aslam, U.; Khalid, B.; Chen, B. Green route to synthesize Zinc Oxide Nanoparticles using leaf extracts of Cassia fistula and Melia azadarach and their antibacterial potential. Sci. Rep. 2020, 10, 9055. [CrossRef]

19. Shah, R.K.; Boruah, F.; Parween, N. Synthesis and Characterization of ZnO Nanoparticles using Leaf Extract of Camellia sinesis and Evaluation of their Antimicrobial Efficacy. Int. J. Curr. Microbiol. App. Sci. 2015, 4, 444-450. 
20. Al-Dhabi, N.A.; Arasu, M.V. Environmentally-friendly green approach for the production of zinc oxide nanoparticles and their anti-fungal, ovicidal, and larvicidal properties. Nanomaterials 2018, 8, 500. [CrossRef]

21. Zhang, Z.; Men, L.; Peng, Y.; Li, J.; Deng, A.; Chen, Y.; Liu, X.; Ma, R. Morphological differences of the reproductive system could be used to predict the optimum Grapholita molesta (Busck) control period. Sci. Rep. 2017, 7, 8198. [CrossRef]

22. Jameel, M.; Shoeb, M.; Khan, M.T.; Ullah, R.; Mobin, M.; Farooqi, M.K.; Adnan, S.M. Enhanced Insecticidal Activity of Thiamethoxam by Zinc Oxide Nanoparticles: A Novel Nanotechnology Approach for Pest Control. ACS Omega 2020, 5 , 1607-1615. [CrossRef]

23. Rajula, J.; Rahman, A.; Krutmuang, P. Entomopathogenic fungi in Southeast Asia and Africa and their possible adoption in biological control. Biol. Control 2020, 151, 104399. [CrossRef]

24. Rouhani, M.; Samih, M.A.; Kalantari, S. Insecticied effect of silver and zinc nanoparticles against Aphis nerii Boyer of fonscolombe (Hemiptera: Aphididae). Chil. J. Agric. Res. 2012, 72, 590-594. [CrossRef]

25. Guan, H.; Chi, D.; Yu, J.; Li, X. A novel photodegradable insecticide: Preparation, characterization and properties evaluation of nano-Imidacloprid. Pestic. Biochem. Physiol. 2008, 92, 83-91. [CrossRef]

26. Khooshe-Bast, Z.; Sahebzadeh, N.; Ghaffari-Moghaddam, M.; Mirshekar, A. Insecticidal effects of zinc oxide nanoparticles and Beauveria bassiana TS11 on Trialeurodes vaporariorum (Westwood, 1856) (Hemiptera: Aleyrodidae). Acta Agric. Slov. 2016, 107, 299-309. [CrossRef]

27. Haroun, S.A.; Elnaggar, M.E.; Zein, D.M.; Gad, R.I. Insecticidal efficiency and safety of zinc oxide and hydrophilic silica nanoparticles against some stored seed insects. J. Plant Prot. Res. 2020, 60, 77-85. [CrossRef]

28. Santos, T.S.; Silva, T.M.; Cardoso, J.; de Albuquerque-Júnior, R.L.C.; Zielinska, A.; Souto, E.B.; Severino, P.; da Costa Mendonça, M. Biosynthesis of silver nanoparticles mediated by entomopathogenic fungi: Antimicrobial resistance, nanopesticides, and toxicity. Antibiotics 2021, 10, 852. [CrossRef]

29. Kalaimurugan, D.; Vivekanandhan, P.; Sivasankar, P.; Durairaj, K.; Senthilkumar, P.; Shivakumar, M.S.; Venkatesan, S. Larvicidal Activity of Silver Nanoparticles Synthesized by Pseudomonas fluorescens YPS3 Isolated from the Eastern Ghats of India. J. Clust. Sci. 2019, 30, 225-233. [CrossRef]

30. Vivekanandhan, P.; Swathy, K.; Thomas, A.; Kweka, E.J.; Rahman, A.; Pittarate, S.; Krutmuang, P. Insecticidal Efficacy of Microbial-Mediated Synthesized Copper Nano-Pesticide against Insect Pests and Non-Target Organisms. Int. J. Environ. Res. Public Health 2021, 18, 10536. [CrossRef]

31. Malaikozhundan, B.; Vaseeharan, B.; Vijayakumar, S.; Thangaraj, M.P. Bacillus thuringiensis coated zinc oxide nanoparticle and its biopesticidal effects on the pulse beetle, Callosobruchus maculatus. J. Photochem. Photobiol. B Biol. 2017, 174, 306-314. [CrossRef]

32. Armstrong, N.; Ramamoorthy, M.; Lyon, D.; Jones, K.; Duttaroy, A. Mechanism of silver nanoparticles action on insect pigmentation reveals intervention of copper homeostasis. PLoS ONE 2013, 8, e53186. [CrossRef] [PubMed] 